\title{
Economic Policies for Growth and Poverty Reduction: PRSPs, Neoliberal Conditionalities and 'Post-Consensus' Alternatives
}

\author{
Terry McKinley'
}

\begin{abstract}
1 Introduction
This article focuses on economic policies and judges their success based on their impact on growth and poverty reduction. The Millennium Development Goal of halving extreme income poverty by 2015 expresses the consensus of the international development community that poverty reduction is of overriding importance. There is also consensus that national poverty reduction strategies, and Poverty Reduction Strategy Papers in particular, are the primary vehicle for focusing national policies on reducing poverty.
\end{abstract}

Beneath this apparent consensus, there are, however, significant differences. This article 'swims against the tide', so to speak, in arguing that such differences are healthy and should be encouraged, and, moreover, that achieving international consensus is not a desirable goal. In this respect, this article 'steals' at least one idea from neoliberal thinking, namely, that a 'marketplace of ideas', in which there is competition among conflicting views, should be promoted.

Ironically, there is not a great deal of space for such a stance in the current climate. Despite their poor performance in the last quarter century, neoliberal policies - which include deregulation, privatisation, macroeconomic interventions that focus exclusively on price stability, and, in general, development strategies that subscribe to the belief that free markets maximise wellbeing - continue to occupy a hegemonic position in economic policymaking and the development discourse. ${ }^{1}$
Compared with the performance of post-colonial policymaking in developing countries, roughly from the 1950s through to the mid-1970s, neoliberal conditionality-based policies have performed poorly, in terms of (1) slow economic growth, (2) greater economic instability, (3) rising inequality, (4) widening underemployment and (5) persistently pervasive poverty. If one questions, for example, the statistical anomaly of a dramatic reduction in poverty in China from 1993 to 1996 (a very short period of time), one is hard pressed to argue that the proportion of the population in extreme income poverty in the world declined in the 1990s.

Of course, neoliberal policies are not without their critics. Within mainstream economics, there has been a recent stream of prominent critics - such as Joseph Stiglitz, Jeffrey Sachs, Nancy Birdsall, Ravi Kanbur and William Easterley - who have broken with particular neoliberal approaches in one form or another. In practice, however, the bulk of external recommendations on economic policymaking being supplied to developing countries remain neoliberal. More importantly, these recommendations are tied to binding conditionalities. Even if national policymakers disagree with the recommendations, they are bound to implement them if they wish their country to receive debt relief or continue receiving concessional lending, or even grant-based technical assistance.

More ominous has been the encroachment of conditionalities across a wide gamut of national policymaking, including social policies and 
governance as well as economic policies. In the early days of structural adjustment, the lives of national policymakers were simpler: economic policies were imposed on them by international financial institutions but they had, at least, some degrees of freedom in how they picked up the pieces thereafter.

At first, conditionalities just applied to macroeconomic policies, but soon they were applied to broader structural issues, i.e. structural adjustment In short order, national policymakers found that they had no real 'ownership' of their own economic strategies and their overall development strategies were soon forced to tail after their economic strategies, or relegate themselves to irrelevance.

As was well documented in the late 1980 s and early 1990s (cf. UNICEF's Structural Adjustment with a Human Face and UNDP's Human Development Reports), structural adjustment imposed heavy social costs in the countries on which it was imposed. In order to foster greater 'national ownership', international financial institutions extended their assistance to constructing social safety nets in order to help mitigate the consequences of adjustment. But since the adverse impact of adjustment continued to be pervasive through the early 1990s, constructing nets was no longer regarded as adequate. By the mid-1990s, these social safety nets were well on their way to being upgraded to national poverty reduction strategies (cf. The 1995 World Summit for Social Development). By 1999, the World Bank and IMF agreed to tie their assistance, and their conditionalities, to the national adoption and 'ownership' of Poverty Reduction Strategy Papers.

Several serious problems remain, despite the shift from structural adjustment to PRSPs. One is the glaring inconsistency between economic policy conditionalities, which continue to be based on neoliberalism, and the social focus of Poverty Reduction Strategy Papers. Reconciling these two approaches has proven to be difficult. Social policies remain ill equipped to undo the detrimental effects of neoliberal economic policies, e.g. economic stagnation, growing underemployment, increasing vulnerability, intensifying insecurity and widespread poverty.

Even when growth occurs in some developing countries, it is often not reaching the poor. This has raised the importance in the international development community of identifying policies that can foster 'pro-poor growth'. This is growth that not only can improve the 'absolute' conditions of poor households (by raising their level of real incomes) but also can enhance their 'relative' conditions vis-à-vis non-poor households (by reducing inequality between the poor and non-poor). This is difficult enough to accomplish under normal capitalist patterns of development but doubly difficult when the governing economic strategy is neoliberal.

In most cases, growth has been too slow and too pro-rich. One might expect the more enlightened rich to remain unsatisfied with such an ambivalent outcome - namely, a larger share of a more slowly expanding pie. There are bound to be diminishing marginal returns to self-aggrandisement under such a scenario. This is, no doubt, one of the factors fuelling the emerging differences within mainstream economics.

In consideration of some of the factors outlined above, UNDP has in recent years begun to critically examine the impact of orthodox economic policies on growth, human development and poverty reduction. It has been motivated by three major concerns: (1) trying to determine, practically, how 'pro-poor growth' can be achieved; (2) trying to reconcile the seeming inconsistencies between neoliberal economic policies and Poverty Reduction Strategy Papers (PRSPs); and (3) trying to promote a broader and healthier policy dialogue on these issues by helping create a larger menu of viable economic options and alternatives.

'Pro-poor growth' is an unlikely outcome unless economic policies and PRSPs are mutually consistent and this consistency is unlikely, in turn, as long as economic policymaking is wedded to economic orthodoxy. In addition, insofar as neoliberalism remains dominant, there is little room for meaningful dialogue and debate on economic policies.

These are the initial lessons from UNDP's support to an array of national studies on Economic Policies and Poverty Reduction in the Asia region (see, for instance, McKinley 2003, 2004; Pasha 2003).

In the following sections, the article concentrates on seven interrelated issues: (1) the links between participation and economic policy dialogue; (2) the ambiguities of 'national ownership' of PRSPs, especially of pro-poor economic policies; (3) the 
'small-government' bias of neoliberalism; (4) the need for pro-active, public-investment based fiscal policy; (5) the roadblock of restrictive inflation targeting; (6) the adverse impact of financial deregulation on poor households; and (7) the adverse impact on the poor of privatisation, particularly privatisation of public services

\section{Enhanced participation and economic alternatives}

The donor community puts a great deal of emphasis on the need for participatory processes in formulating Poverty Reduction Strategy Papers. Enhanced participation is certainly essential to building more effective strategies but it does not, by itself, guarantee pro-poor outcomes. In many cases, participation has been mostly a governmentsponsored one-off consultation with civil-society organisations and community groups, designed to elicit a rubber stamp for strategies already formulated.

In other words, participation has been more about process than substantive content; it has seldom been about exploring alternatives, especially economic alternatives, and engaging in debate on policy differences. Civil society representatives have often had little substantive input into PRSPs and little chance of influencing programme design. The call by the international donor community for national 'ownership' of PRSPs usually implies that national stakeholders are encouraged to agree with a predetermined set of external policy recommendations. They have had little opportunity to choose among various policy options, much less formulate their own.

At best, the scenario is one of 'choice-less' participation, with negligible scope for real policy choice. The most severe problems are in the realm of economic policymaking. In this area, there is still little latitude for choice or debate. External conditionalities remain tightly binding, despite the recent muted rituals of critical self-examination, generated by the research departments and independent evaluation offices of international financial institutions.

If PRSPs, and their economic content in particular, were nationally determined, several conditions would be necessary. First, the one-size-fits-all approach should be jettisoned and strategies should be tailored to country-specific contexts. Second, citizens should be presented with real policy choices in poverty reduction strategies. Third, there should be broadbased national debate and dialogue before a strategy is finally adopted.

A participatory process for determining pro-poor economic policies must be based on examining a range of credible alternatives. However, policymakers and citizens are often led to believe that there is no alternative to the conventional set of structural adjustment policies. This is where progressive economists should be focusing most of their attention, providing feasible economic policy options, based on alternative development paradigms. So far, much of the economic critique of neoliberal policies is based on Keynesian or post-Keynesian perspectives. There is, in fact, little real diversity of dissent and usually only moderate critiques of the mainstream.

\section{3 'National ownership' vs. conditionality}

The Bretton Woods Institutions and the donor community at large often proclaim the need for national 'ownership' of poverty reduction strategies, including Poverty Reduction Strategy Papers (PRSPs). What is needed, however, is national empowerment over policy formulation, not merely national 'ownership'. National 'ownership' of such strategies is a donor obsession, not a government objective. Governments are being urged to adopt 'as their own' policies introduced by outside agencies - without real policy autonomy in designing 'home-grown' strategies.

There is, in fact, an inherent conflict between national determination of policies and lender conditionalities - hence the focus of lenders on questions of ownership. The conditions imposed by international financial institutions on national policymaking have become increasingly comprehensive. The conditionalities of the IMF have extended, for example, well beyond its original mandate of monetary, fiscal and exchange rate policies. But as the range of conditionalities has expanded, not surprisingly the rate of national compliance has diminished (Buira 2003).

The Bretton Woods Institutions now place a great deal of emphasis on supporting capacity development for national 'ownership' of PRSPs and their associated economic policies. But there is again an inherent conflict of interest for the external institutions that set the conditionalities for countries to try to promote national policy autonomy. 
Poverty Reduction Strategy Papers have replaced Structural Adjustment Programmes as the basis for World Bank and IMF lending. Thus, they have to be approved by their executive boards. In the process, conditionalities have spread to cover all important economic decisions and many structural policies, social measures, governance reforms and, last but not least, anti-poverty strategies themselves.

Yet the position of both the Bank and the Fund and many international donors is that PRSPs should be 'nationally owned', 'home-grown' strategies, Additionally, these institutions have agreed to 'align and harmonise' their operations with the PRSPs assuming, heroically, that they are 'nationally owned'. The Bretton Woods institutions have also lobbied to have all other donors align their assistance with the PRSP framework.

If PRSPs were genuinely 'home-grown', they should exhibit a wide diversity of approaches. However, dominated by international priorities, these strategies are remarkably uniform (Stewart and Wang 2003).

This is most evident in their macroeconomic policies. The IMF's Poverty Reduction and Growth Facility, which sets most macroeconomic policies for borrowing countries, should be based on the PRSPs. But the reverse has been the case.

Partly because most PRGFs have been negotiated before PRSPs, they have bypassed any national dialogue or debate, in which various policy options could be evaluated. The PRGF macroeconomic framework is imported virtually without change into the PRSP. And national policy autonomy is sacrificed in the process. Such an approach guarantees that, in practice if not in theory, there is indeed no viable alternative to neoliberalism.

\section{Small government is the problem, not the solution}

A small government bias governs all neoliberal economic reforms. Structural adjustment policies have led to substantial downsizing of the state in many developing countries - debilitating their capacities to formulate and implement the pro-poor policies that are now required for PRSPs. Tax reforms have combined with recessions to depress the revenue levels for many governments. Cutting expenditures has been heartily endorsed, especially for public administration, but raising taxes has been only mildly supported.
As a consequence, many governments in developing countries lack enough revenue to invest in growth and fight poverty. A pervasive 'small-government ideology' hides the reality that governments are starved of resources, unable to adequately finance many essential public services. Poor households end up as the main losers. While directing more money to pro-poor expenditures is part of the answer, raising more funds is also critical - but frequently neglected. The domestic revenue base of most developing countries is too small, not too big.

The main problem is the lack of tax revenue. For all developing countries, tax revenue as a ratio to GDP is about half the level of industrial countries (i.e. 18 per cent vs. 38 per cent) (Tanzi and Zee 2001). In poor countries, such as Bangladesh, Guatemala, Guinea, Madagascar and Nepal, the total revenue is only 10-11 per cent of the GDP, or less.

Moreover, in many countries, total revenue as a percentage of GDP has fallen, weakening the capacity of the state to promote development. In Bangladesh, for example, the ratio of total revenue to GDP dropped from about 12 per cent in 1990, an already low level for a poor country, to only 10 per cent in 2000. During the same period, the ratio for Indonesia dropped from about 19 per cent to 16 per cent and in Sri Lanka from 21 per cent to 17 per cent.

This downsizing of public budgets poses several problems. The state is hampered in playing a significant redistributive role through taxes and expenditures. This is occurring at the same time that the international donor community is compelling countries to implement PRSPs, which must necessarily have a redistributive impact to be effective. Also, when the public budget is small, governments are unable to use fiscal policy as a counter-cyclical tool for stabilisation of the economy. The weight of government expenditures in relation to the whole economy is simply too small.

Standard tax reforms do not provide the answer to boosting revenue. Trade liberalisation has significantly reduced trade taxes - a big source of revenue for many poor countries. In Indonesia, for instance, weighted mean tariffs on all products are only about 5 per cent, while in Sri Lanka they are only about 7 per cent.

The main replacement for trade taxes, the valueadded tax (VAT) on consumption of goods and 
services, is often regressive. Because the poor have to use most of their income for basic consumption, at least the food or other essential items that they consume should be exempted. By contrast, the income and wealth of the rich are under-taxed, because of loopholes and/or poor enforcement of tax laws. Tax concessions to the rich are estimated, for example, to be equivalent to about 4 per cent of GDP in Pakistan.

Having the rich pay their fair share of taxes would thus be an important response to the problem. Tax systems should be more equitable as well as more efficient. The poor should not pay proportionately more taxes than the rich, nor should they receive proportionately fewer public benefits. A lot of attention has been paid to re-allocating expenditures to the poor. More needs to be done to reform tax systems to make their impact more equitable. Tax reformers could both broaden the tax base and make tax incidence more equitable by closing such loopholes while lowering rates on indirect taxes, such as the VAT, which tend to be regressive (Pasha 2003).

Thus the big priority for tax reform is to change the composition of taxes away from regressive consumption taxes and towards progressive income and wealth taxes. In industrial countries, the ratio of income to consumption taxes is more than double that of developing countries (Tanzi and Zee 2001). More could certainly be done to tax wealth, which is often neglected as a source of revenue. Urban property taxes could be raised in most countries. Simply registering urban property, doing accurate valuation of property values and modestly raising property tax rates could contribute significantly to boosting revenue. Even mainstream economists now recognise that there is greater scope for raising revenue from property taxes (Williamson 2003).

\section{The key role of public investment in growth and poverty reduction}

In most developing countries, more expansionary fiscal policies are needed to accelerate economic growth. Fiscal policies are also needed to play a counter-cyclical role in stabilising the economy. Moreover, the growth stimulated by fiscal expansion can help generate the fiscal revenue needed to close any deficits incurred in the process of expansion, depending on the elasticity of taxes with respect to GDP.
Such policy recommendations are based on the assumption that the economies of most developing countries are demand-constrained, not priceconstrained (Weeks and Roy 2004). An economy is demand-constrained when its level of output is limited by the components of aggregate demand, namely, consumption, private investment, government expenditures and net exports. In such an economy, the set of relative prices derives from the level of aggregate demand and changes in response to the rise or fall of aggregate demand. Relative prices are not 'signals' to producers and consumers but result from production and consumption decisions. When total aggregate demand is deficient, active fiscal policies play a central role in moving the economy towards full employment and generating a higher growth rate.

Within this context, public investment plays a crucial role in accelerating the rate of economic growth, both by providing a demand stimulus to the economy and expanding its productive capacity. Such investment can also play an important role in allocating resources to the poor - namely, it can give the pattern of growth a more pro-poor character. Thus, public investment is essential to a pro-poor and pro-growth economic strategy for three major reasons: demand management, capacity expansion and redistribution (Weeks and Roy 2004).

Public investment is not the enemy of private investment, as neoliberal economics claims, but its prerequisite. It is essential for basic social and physical infrastructure. When well-designed public investment boosts the productivity of labour and capital and enhances profit expectations, it stimulates more private investment, instead of 'crowding it out' as is often mistakenly maintained. In Indonesia, for example, regression analysis for the period 1972-97 demonstrated that every 1 percentage point increase in public investment translated into an increase of a 0.66 percentage point in private investment. Crowding-out is unlikely when an economy is not near full employment (as is the case in almost all developing countries) and the capital-output ratio for public investment is no higher than for private investment (Weeks and Roy 2004).

Instead of focusing on public investment, many international donors have become champions of 'private-sector development' and boosting 'investor confidence' to trigger more private investment. 
However, although growth of the private sector is desirable, it is not equivalent to development. Moreover, the private sector cannot grow without public investment in basic economic and social infrastructure that stimulates expansion of the economy. Without growth, the private sector cannot generate profits; and without profits, there will be little motivation for private investment, domestic or foreign.

Economists favouring neoliberal policies also argue that increasing public investment will enlarge public deficits and that these, in turn, will fuel higher inflation, depreciation of the exchange rate and higher real rates of interest. However, there is little empirical evidence from economic literature that public investment crowds out private investment through changes in the interest rate or exchange rate (Hemming et al. 2002). Moreover, the multiplier impact of public investment can be powerful if there is excess capacity in an economy and households are liquidity constrained - as is the case in many developing countries.

Many rich-country advisers often argue against expansionary fiscal policies - except in their own countries. In the USA, for example, between the third-quarter of 2000 and the third-quarter of 2003 , there was an astonishing fiscal stimulus of US $\$ 638$ billion, or 6 per cent of the 2003 GDP (Izurieta 2003). But this stimulus took the form of tax cuts rather than increases in public expenditures and the tax reductions mainly benefited the rich. On average, however, the multiplier impact on an economy of a tax cut is half as powerful as that of an increase in expenditures (Hemming et al. 2002). If the rich get the benefits, the impact is even weaker. This implies that for pro-poor growth, make sure: (1) public investment is increased and (2) it benefits the poor.

Despite the pressing need for more public investment, it remains low where it should be high, namely, in low-income countries with under-supplied public goods. In many countries, it is also falling. In South Asia, capital expenditures were only 9 per cent of the total public expenditures in 2000, down from 12 per cent in 1990. As a percentage of GDP, public investment should be over 5 per cent in most developing countries. But in many countries, it is well below this level. In Pakistan, for instance, public investment is currently 2.5 per cent, in Zimbabue 2.1 per cent, and in Georgia a mere 0.4 per cent.
Public investment is also critical to poverty reduction, but not just for basic education and health - on which everyone now agrees - but also for such essential infrastructure as rural roads, energy and irrigation. Increased growth cannot benefit the poor without more rural and agricultural development. This is precisely where public investment is most needed, and most lacking.

\section{Tight inflation targets as roadblock to growth}

The multipliers for fiscal expansion remain large, particularly when a moderate monetary expansion accompanies an increase in public investment. However, neoliberal policies are biased towards tight monetary policies. The emergence of huge magnitudes of mobile finance capital along with capital account liberalisation have favoured the implementation of deflationary policies as a way of preventing capital outflows by both foreign and domestic investors (Patnaik 2003). Such policies have contributed to tightening demand constraints on developing country economies, in the name of promoting macroeconomic stability and investor confidence.

However, under such conditions, it is urgent to advocate for income stability as well as price stability to emphasise employment targeting as well as inflation targeting. Slow growth and low employment hurt the poor more than anyone else. Inflation is not their only problem. While moderate inflation can be compatible with growth, both low and high inflation can be harmful (Chowdhury 2003). When lowinflation policies drive an economy into recession, the poor lose out, often for years thereafter.

Monetary policy is too important to be left to central bankers. Without jobs and income, people cannot benefit from price stability. Inflation targets should be determined, not independently by technocrats, but by government-wide and democratic decisionmaking. The monetary specialists can then be left to craft the means.

Most developing countries have been advised to reduce their annual inflation rate to a 3-5 per cent range - a usual conditionality for obtaining access to concessionary loans. And many national central banks have been given the independence to achieve this monetary goal - despite any adverse consequences for growth, employment and poverty. Apparently, some economic policies are too important to be subject to democratic decision-making. 
Average inflation in the developing world has declined to its lowest level, namely, about 4 per cent, since the 1960s. Recently, the main problem for over one-quarter of these countries, especially in Asia, has not been inflation, but deflation (a sustained fall in the general price level). During 2000-01, for example, the inflation rates in Cambodia and Vietnam were -0.6 per cent and -0.4 per cent, respectively. In Bangladesh and China, the inflation rates were 1.1 per cent and 0.3 per cent, respectively - rates that were perilously close to deflation given the upward bias of the CPI measure. A major factor contributing to the danger of deflation has been unnecessarily restrictive monetary policies. Another factor has been a slowing global economy.

The danger created by deflation is that it can precipitate a self-reinforcing downward spiral of prices, profits and incomes, from which it is difficult for policymakers to extricate an economy. Monetary policies are usually ineffective when an economy has slipped into such a 'liquidity trap'. Thus, it is better to prevent deflation than to try to combat it once it sets in. For such a purpose, it is often necessary to deploy counter-cyclical fiscal policies. Once deflation is entrenched, expansionary fiscal policies are also more reliable than monetary policies in reviving the economy (IMF 2003).

There is no evidence that very low inflation is good for growth. Many studies confirm that moderate inflation - certainly above 5 per cent and at least up to 15 per cent - can have a positive effect on growth (Pollin and Zhu 2006). The standard justification for minimising inflation is that it hurts the poor. But this misreads the facts: very high, destabilising inflation (such as above 40 per cent) definitely hurts the poor. And very low inflation (below 5 per cent) can also harm their interests by impeding growth and employment.

When central banks try to squelch inflation, the economy is often driven into a 'stabilisation trap' (Chowdhury 2003). Looming on the horizon is deflation, the self-reinforcing downward spiral of prices, profits, output and employment.

\section{The dismal record of financial deregulation}

One of the cornerstones of recent economic reforms has been financial deregulation. But the record of such deregulation has been neither pro- poor nor pro-growth. It has often destabilised the economies of developing countries and denied access of poor households to credit. Under liberalisation, real interest rates have risen and the spread between the deposit and lending rates of interest has widened. In 2001, the real rate of interest in Bangladesh, for example, was 14 per cent and the spread between deposit and lending rates of interest was over 7 percentage points. In Cambodia, this spread was over 12 percentage points in 2001.

Commercial banks have tended to concentrate their activities in a few urban areas, depriving the rural population of access to financial services. This has made access to credit more inequitable than before liberalisation. Banks have been reluctant to lend in rural areas, especially if the rural economy is stagnant. But even in China, which has maintained a rural financial system, the Agricultural Bank of China and the rural credit cooperatives have retrenched their operations in rural areas, hampering the prospects for rural growth and poverty reduction.

Under liberalisation, banks and corporations have resorted more to short-term external borrowing, making the country more vulnerable to short-term capital flight - and wreaking havoc on the economy in times of crisis. When the economy is booming, 'hot money' rushes in to make a quick profit, but this sows the seeds of financial instability.

In the face of rising criticism of financial deregulation, the IMF has recently conducted research on the topic but it has failed to find a positive relationship between financial liberalisation and economic growth (Prasad et al. 2003). The available evidence points, in fact, to an association between capital account liberalisation and heightened vulnerability to crises. Thus, the economic mainstream has begun to move away from unqualified support for free capital movements. As Williamson has noted recently, 'financial liberalisation often occurred without the appropriate complement of prudential supervision' (Williamson 2003: 2).

The mainstream is still committed to liberalisation but stresses the importance of a conducive environment, such as 'prudential supervision' (as Williamson argues) or sound domestic institutions (as the IMF now emphasises for capital account liberalisation). The result: developing countries are still primarily to blame for their financial woes, not 
the pro-cyclical nature of external capital flows or the poor quality of external advice. Also, despite recent expressions of misgivings, financial liberalisation continues as a central ingredient of standard structural adjustment programmes. In practice, national policymakers have to contend with only marginally reformed liberalisation.

Meanwhile, for poverty reduction purposes, the international donor community continues to focus myopically on microfinance when it should be addressing the fundamental problems created by unregulated financial liberalisation. Without state support, for instance, a rural banking system is seldom sustainable and equitable. Under a regime of 'free capital movements', farmers and non-farm enterprises are customarily deprived of adequate levels of credit, which are crucial to reduce poverty.

In addition, long-term investment is constrained as commercial banks increasingly focus on short-term lending, such as for consumer durables or working capital. This is a major problem, for instance, in Indonesia, where banks maintain high real lending rates of interest - despite a reduction in policy rates of interest - because they are reluctant to commit credit to long-term private investment. In such a situation, the inflow of speculative capital only exacerbates the short-term horizon of investors. Indonesia is now attracting short-term portfolio investment, not foreign direct investment, but such 'hot money' only magnifies the country's vulnerability to a new crisis.

Without stronger regulation and effective supervision, financial institutions will promote neither sustainable nor equitable growth. But direct state support to the provision of development finance is also needed (Chandrasekhar 2004). Private financial institutions provide relatively little long-term investment finance. The lack of such finance has been a problem in Sri Lanka, for example, since the privatisation of the staterun Development Finance Corporation of Ceylon and the National Development Bank. In contrast, Vietnam has continued to support a heavily financed Development Assistance Fund for directing credit to priority industries.

In summary, unfettered financial deregulation hurts growth and harms the poor. Contrary to the liberalisation mania, the international development community should advocate for more regulation of the financial sector, including foreign short-term borrowing, because more equitable access to financial services will help foster financial stability and economic growth. Donor assistance should expand beyond microfinance to encourage public sector support to development finance, and, in particular, to rural banking systems and financial institutions serving small and medium enterprises. If SMEs in urban centres and rural areas cannot obtain access to credit, widespread employment at decent wages - a prerequisite for sustainable poverty reduction - will not be created.

\section{Questioning the contribution of privatisation}

Privatisation of state-owned enterprises (SOEs) and other publicly owned assets, such as land and housing, has been an integral component of neoliberal economic reforms. The justification has been that public ownership of assets is inefficient because it distorts incentives, hampers resource allocation and impedes innovation. In addition, it is alleged that state-owned enterprises are a drain on public resources and a source of rent-seeking and corruption.

However, the evidence on the impact of privatisation on efficiency has been generally unconvincing (Dagdeviren and Fine 2004). In some cases, efficiencies can be improved without changing ownership of assets. Privatisation appears to be less important, in most cases, than competition and regulation. Once the latter two factors are taken into account, the contribution of privatisation to efficiency is often statistically insignificant.

Also, the long-term impact of privatisation on government budgets remains unclear - especially when profitable SOEs, which are the most attractive to private buyers, are sold at fire-sale prices. When sale prices are low and the administrative costs of privatisation are taken into account, the net proceeds from selling SOEs might well be negative. In addition, over the long term, the taxes paid by privatised firms, which are likely to be low, might not compensate for the loss of the profits of the SOEs. Also, the balance sheet would be even more negative if the costs of regulation of the privatised firm were taken into account.

Little research has been done, until recently, on the distributional impact of privatisation, particularly on the poor. Privatisation of the provision of public 
services, such as water, energy and social services, has often led to less coverage and higher prices for poor households (Kessler 2003).

In transition economies, the drive to privatise land, in the name of boosting efficiencies, has threatened to magnify poverty by intensifying inequality in the distribution of land and increasing landlessness. This has been a problem, for example, in Cambodia, which privatised land in 1989 (Dagdeviren and Fine 2004). In Mongolia, privatisation of the ownership of livestock has also led to greater inequality (Nixson and Walters 2003). In countries, such as China and Vietnam, where use-rights to the land are distributed relatively equitably, using privatisation to redistribute land to private farmers is a reform of questionable value, because it is fraught with the danger of dramatically augmenting rural poverty.

When public wealth is converted into private wealth, the distribution of wealth usually becomes more unequal. Even when equity-enhancing methods, such as 'voucher' privatisation in Mongolia, have been used, an initially egalitarian distribution of privatised assets has quickly become more unequal as a few oligarchs buy up the certificates of ownership. In many cases, privatisation of SOEs has done nothing to reduce rent-seeking and corruption. By boosting the economic power of oligarchs, privatisation has contributed, if anything, to more corruption.

\section{Conclusion: a tripartite policy framework for pro-poor growth}

If polices are to promote pro-poor growth, we may need to think in terms of a tripartite analytical framework that integrates three major sets of policies: macroeconomic policies, structural policies (which impact the structure of production and the nature of economic institutions) and equity-enhancing policies. If macroeconomic policies are to stimulate investment and growth, they may need to break with neoliberal prescriptions and take macroeconomic stability as a constraint rather than an objective. Fiscal policies will have to become more expansionary in nature, more focused on public investment to expand economic opportunities as well as stimulate aggregate demand. They will have to become more reliant on the mobilisation of domestic revenue (instead of official development assistance) to finance such public investment. This stance implies a strong focus on the supply side, e.g. on expanding productive capacity and mobilising domestic resources.
It would also imply a managed instead of a laissezfaire exchange-rate regime, a focus on containing external shocks (such as terms-of-trade or capital outflow shocks) and a focus on maintaining a competitive exchange rate (which, if possible, should be slightly under-valued). And finally, it would imply monetary policies designed to support fiscal expansion and export promotion, provide adequate liquidity to a growing economy and foster low but positive real rates of interest for private (and public) investment. Strict inflation targeting (especially a monetary stance that seeks to achieve a low inflation target, such as under 5 per cent) would be inconsistent with such an approach.

Structural policies should then be used to influence the pattern of growth so as to structure access to economic opportunities and employment, and thus have a potentially strong distributional impact. Thus, the impact of fiscal policies can be differentiated by economic sector or employment category (e.g. the location of public investment in infrastructure). Access to financial services can be differentiated, such as increasing access to credit in rural areas. Industrial policies can be used to channel resources differentially to various economic sectors or subsectors (e.g. to tradables rather than to nontradables). Trade policies can be adjusted by sector or subsector. For purposes of fostering food security, for example, tariffs could be used to protect agriculture in a poor country. The public-sector provision of services can also be calibrated to have differential impacts across the population.

However, even if such policies were successful in stimulating both faster growth and broader employment generation, there would still be no guarantee that poor workers could benefit from such trends. Hence, there is a compelling need for a third set of 'equity-enhancing' or 'poverty focused' policies. These often involve enhancing the access of the working population to education, skill development, technology, land, other productive assets (such as tools and equipment) and public infrastructure. Many households are poor precisely because their working members lack such access.

Correcting such inequities can often involve reshaping or re-focusing the impact of structural policies. An example would be providing the financial system with greater incentives to offer services, such as microfinance to micro-entrepreneurs. Or equity- 
enhancing policies could involve the focusing of resources on certain social groupings. This could take the form, for instance, of providing employment guarantee programmes for such unemployed or underemployed workers.

Spreading the benefits of growth through structural policies can make growth more 'inclusive' - in the sense of not leaving the poor 'behind'. In contrast, equity-enhancing policies can help make growth more 'pro-poor', i.e. benefiting poor workers and households more than proportionately. However, such a 'pro-poor' impact can be achieved only

\section{Notes}

* The positions expressed in this article are the author's and do not necessarily reflect those of UNDP.

1 This article uses 'neoliberal' and 'neoliberalism' primarily as descriptive terms to denote the

\section{References}

Buira, Ariel (2003) 'An Analysis of IMF Conditionality', in Ariel Buira (ed.), Challenges to the World Bank and IMF: Developing Country Perspectives, papers for the G-24 Research Program, London: Anthem Press

Chandrasekhar, C.P. (2004) 'Financial Liberalization and the Macroeconomics of Poverty Reduction', draft thematic summary on financial liberalisation for the Asia-Pacific Programme on the Macroeconomics of Poverty Reduction

Chowdhury, Anis (2003) 'Poverty Reduction and the "Stabilization Trap" - The Role of Monetary Policy', draft thematic summary on monetary policy for the Asia-Pacific Programme on the Macroeconomics of Poverty Reduction

Dagdeviren, Hulya and Fine, Ben (2004) 'Privatization in the Asia-Pacific', draft thematic summary on privatisation for the Asia-Pacific Regional Programme on the Macroeconomics of Poverty Reduction

Hemming, Richard, Kell, Michael and Mahfouz, Selma (2002) The Effectiveness of Fiscal Policy in Stimulating Economic Activity - A Review of the Literature, IMF Working Paper, WP/02/208, December, Washington DC: International Monetary Fund

IMF International Monetary Fund (2003) Deflation:

Determinants, Risks and Policy Options - Findings of through an explicit and focused allocation of resources on poor households and individuals.

To be successful, equity-enhancing policies also need to be more 'bottom-up' in their approach, mobilising among communities, for example, in order to press for more or better public services or to help link poor workers with available employment opportunities. In contrast, structural policies are more 'top-down' in their approach while macroeconomic policies just stay 'at the top', dealing with economy-wide aggregates.

dominant paradigm dictating macroeconomic and adjustment conditionalities enforced by the Bretton Woods Institutions since the 1980s.

an Interdepartmental Task Force, 30 April,

Washington DC: IMF

Izurieta, Alex (2003) 'Slow Recovery Fable in Growth-Recession Times?: An Appraisal of US Main Imbalances and Implications for the World Economy', paper prepared for the meeting of the G-24 Technical Group, Geneva, 15-16 September Kessler, Tim (2003) Assessing the Risks in the Private Provision of Essential Services, Discussion Paper contributed by the Citizens' Network on Essential Services for the G-24 Technical Group, Geneva, Switzerland, 15-16 September

McKinley, Terry (2004) 'Macroeconomic Policy in Transition Economies', draft report prepared for the Initiative for Policy Dialogue, Columbia University, New York

McKinley, Terry (2003) The Macroeconomics of Poverty Reduction: Initial Findings of the UNDP Asia-Pacific Regional Programme, UNDP Discussion Paper, Bureau for Development Policy, UNDP: New York, www.networkideas.org

Nixson, F. and Walters, B. (2003) Privatization, Income Distribution and Poverty-Mongolian Experience, Sydney: Asia-Pacific Press

Pasha, Hafiz A. (2003) 'Pro-Poor Policies', paper prepared for the ICNRD conference, 10-12 September, Mongolia, Regional Bureau for Asia and the Pacific, New York: UNDP, www.asiapropoor.net 
Patnaik, Prabhat (2003) 'The Macroeconomic Underpinnings of Poverty', paper prepared for the International Workshop on 'Tools for the Ex Ante Poverty Impact Assessment of Macroeconomic Policies', 14-15 October, Washington DC: IFPRI Pollin, Robert and Zhu, Andong (2006) 'Inflation and Economic Growth: A Cross-Country Non-Linear Analysis', Journal of Post Keynesian Economics 4 593-614

Prasad, Eswar, Rogoff, Kenneth, Shang-Jin Wei and Ayhan Kose, M. (2003) Effects of Financial Globalization on Developing Countries: Some Empirical Evidence, 17 March, International Monetary Fund

Stewart, Francis and Wang, M. (2003) Do PRSPs Empower Poor Countries and Disempower the
World Bank, Or Is It the Other Way Around?, Working Paper 108, Oxford: Queen Elizabeth House, University of Oxford

Tanzi, Vito and Zee, Howell (2001) 'Tax Policy for Developing Countries', Economic Issues, 27 March, Washington DC: International Monetary Fund

Weeks, John and Roy, Rathin (2004) 'Fiscal Policy for Pro-Poor, Investment-led Growth', draft thematic summary on fiscal policy for the Asia-Pacific Programme on the Macroeconomics of Poverty Reduction

Williamson, John (2003) 'From Reform Agenda to Damaged Brand Name: A Short History of the Washington Consensus and Suggestions for What To Do Next', Finance and Development, September, Washington DC: IMF 